Canadian Journal of Fisheries and Aquatic Sciences

Canadian

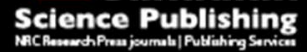

Journal canadien des sciences halieutiques et aquatiques

\title{
Seasonal Hydrology Shifts Production Sources Supporting Fishes in Rivers of the Lower Mekong Basin
}

\begin{tabular}{|r|l|}
\hline Journal: & Canadian Journal of Fisheries and Aquatic Sciences \\
\hline Manuscript ID & cjfas-2015-0214.R3 \\
\hline Manuscript Type: & Article \\
\hline Date Submitted by the Author: & 04-Jan-2016 \\
\hline Complete List of Authors: & $\begin{array}{l}\text { Ou, Chouly; Texas A\&M University, Department of Wildlife and Fisheries } \\
\text { Sciences; The School for Field Studies } \\
\text { Winemiller, Kirk; Texas A\&M University, }\end{array}$ \\
\hline Keyword: & Cambodia, food web, stable isotope ratio, dam, basal source \\
\hline \multicolumn{2}{|c}{} \\
\hline
\end{tabular}

SCHOLARONE ${ }^{\text {IM }}$

Manuscripts 
1 Seasonal Hydrology Shifts Production Sources Supporting Fishes in Rivers of the Lower

\section{Mekong Basin}

3

4 Chouly $\mathrm{Ou}^{*}$

5 Kirk O. Winemiller

6

7 Department of Wildlife and Fisheries Sciences, and Program of Ecology and Evolutionary

8 Biology, Texas A\&M University, College Station, TX 77843-2258, USA

9

10 Corresponding author, Kirk O. Winemiller (email: k-winemiller@tamu.edu)

11

12 *Present address: The School for Field Studies, 100 Cummings Center, Suite 534-G, Beverly, 13 MA 01915, USA

14 


\section{Abstract}

Seasonal hydrology is assumed to be an important reason why the lower Mekong Basin

17 supports highly productive and biodiverse inland fisheries. We used $\mathrm{C}$ and $\mathrm{N}$ stable isotope ratios

18 of tissue samples to estimate primary production sources supporting fish biomass in the Mekong

19 and three large tributaries in Cambodia. We used a Bayesian mixing model to estimate relative

20 contributions of four alternative production sources - seston, benthic algae, riparian grasses, and

21 riparian macrophytes. There was little seasonal variation in isotopic signatures of riparian plants,

22 but benthic algae and seston showed large seasonal shifts in carbon ratios. Seston and benthic

23 algae were the most important production sources supporting fish biomass overall during the dry

24 season, and riparian vegetation was the most important source during the wet season. Sources

25 contributed differentially to biomass of trophic and habitat guilds, especially during the dry

26 season. A dam on the upper Sesan River has changed hydrology, channel geomorphology and

27 other factors, and, compared to the other three rivers, its fish biomass appears to derive from

28 algae to a greater extent.

30 Key words: Cambodia, dams, flood pulse, food web, MixSIR model, stable isotope ratio, tropical 31 river 


\section{Introduction}

The natural flow regime is crucial for sustaining native aquatic biodiversity and maintenance of ecological processes in fluvial ecosystems (Bunn and Arthington 2002; Jardine et al. 2015). A literature review of ecological responses to altered flow regimes revealed a strong relationship between changes in flow components (e.g. flow magnitude, frequency, duration, timing, and rate of change) and changes in geomorphological and ecological dynamics (Poff and Zimmerman 2010). Flow regime alteration directly affects river ecology by changing physical disturbance dynamics, nutrient cycling, availability of basal resources, passive transport of production sources, and top-down control of basal resources (Power et al. 1996; Montoya et al. 2006; Roelke et al. 2006; Winemiller et al. 2006, 2014). Changes in the timing of flow components alter the seasonal regime of flooding which, in turn, affects fish migration, availability and access of instream and off-channel habitats for aquatic organisms, resource availability, and riparian community structure (Junk et al. 1989; Winemiller 2004; Roach 2013). Humans have changed river flow regimes worldwide, especially through impoundment (Poff et al. 1997, 2007; Dudgeon 2000). River impoundments have caused major environmental and social impacts throughout the world. By negatively affecting biodiversity, dams have threatened food security, livelihoods and cultural values of people living along downstream reaches (Richter et al. 2010). Fishes are sensitive to flow regime alteration, with many native species responding with declines in reproduction, recruitment, and population abundance (Dudgeon 2010; Poff and Zimmerman 2010). Dams also trap sediments, which can alter sediment dynamics and geomorphology in downstream reaches and deltas (Kondolf et al. 2014). For example, research on the Paraná River (in Brazil) has revealed greater water clarity and ecological regime shifts in downstream reaches following dam construction (Hoeinghaus et al.

5 2007; Agostinho et al. 2008). 
Knowledge of river food web ecology is essential for management of anthropogenic

impacts on fluvial ecosystems and their valuable services and resources (Winemiller 2004).

Three widely-cited river food web models predict the sources of production that support aquatic organisms: the River Continuum Concept (RCC), the Flood-Pulse Concept (FPC) and the Riverine-Productivity Model (RPM). According to the RCC, fine particulate organic material originating from dead leaves and woody debris in upstream reaches are important inputs to large river food webs (Vannote et al. 1980). The FPC proposes that lateral connectivity between the main channel and floodplain habitats is important in large river food webs. FPC predicts that ecosystem dynamics are driven by seasonal floodplain inundation that introduces terrestrial material (e.g. invertebrates and macrophyte biomass) to the aquatic food web (Junk et al. 1989).

The RPM stresses algal-grazer pathways as the main food chains maintaining fish diversity and production in large river food webs. The RPM hypothesizes that consumers obtain most of their carbon from autochthonous sources (e.g. benthic algae and phytoplankton) growing in the river channel, and a lesser amount of carbon is assimilated from sources in the riparian zone (Thorp and Delong 1994).

River food webs have been demonstrated to have both temporal and spatial variation in response to variation in abiotic factors and/or species composition (Winemiller 1996; Jardine et al. 2015). None of the three models mentioned above integrate all the key dimensions and drivers of watershed characteristics (e.g. discharge, turbidity, sedimentation, light penetration) that affect temporal and spatial food web variation. A recent review of production sources for river food webs concluded that, in rivers with rates of high erosion and sedimentation, aquatic consumers assimilate algae during low-water periods when water transparency is high, and during high-flow periods when water transparency is low, $\mathrm{C}_{3}$ plants become a more important source supporting 
79 consumer biomass (Roach 2013). Biochemical research on the Lower Mekong River in

80 Cambodia, a sediment-laden river, indicated that during the dry season, fine particulate organic

81 matter (FPOM) suspended in the water column is mostly derived from algae, and, during the wet

82 season, it is mostly derived from vascular plants (Ellis et al. 2012).

83 In this study, we investigated primary production sources supporting fish biomass in the

84 Lower Mekong River and three major tributary rivers in Cambodia. We estimated seasonal

85 variation in contributions of primary production sources to fish assemblages in three rivers that

86 have relatively low impact from dams and one river (Sesan) significantly impacted by upstream

87 dams. We estimated basal production source contributions during the dry season when river

88 discharge is low and water is relatively transparent. We repeated field surveys and estimates

89 during the wet season when river discharge is high and variable and water is turbid. In

90 accordance with Roach's (2013) model, we hypothesized that autochthonous primary production

91 sources (algae) would support most fish biomass during the dry season, and allochthonous

92 sources $\left(\mathrm{C}_{3}\right.$ plants) would be more important during the wet season. We further hypothesized

93 that the river impacted by dams would reveal divergent patterns of seasonal assimilation of

94 material originating from principal basal production sources.

96 Methods

97 The Mekong River

98 The annual flood pulse of the Mekong River supports one of the world's most productive

99 and biodiverse inland fisheries (Welcomme 1979). Globally, the Mekong is the tenth longest

100 river with the eighth greatest discharge and third richest in fish species richness (Welcomme

101 1985). Over one thousand fish species, belonging to 24 orders and 87 families, and more than 
102 two hundred endemic freshwater species have been documented in the river (Mekong River

103 Commission 2003). Estimates of fish biodiversity in the basin are conservative because there

104 continually are new discoveries (Rainboth et al. 2012). The river contains several iconic aquatic

105 species, including the giant Mekong catfish (Pangasionodon gigas), one of the largest freshwater

106 fishes in the world, which can reach $300 \mathrm{~kg}$, giant Mekong carp (Catlocarpio siamensis), giant

107 stingray (Himantura chaophraya), and Irrawaddy freshwater dolphin (Orcaella brevirostris).

108 The Mekong River's natural flow regime and its fish diversity will be impacted by

109 hydropower development in the region (Adamson et al. 2009; Dugan et al. 2010; Grumbine et al.

110 2012; Ziv et al. 2012). Three hydroelectric dams were completed in the Upper Mekong mainstem

111 in China in 1995, 2003 and 2008 (Barlow et al. 2008). More than 100 dams have been proposed

112 for the Lower Basin countries of Cambodia, Laos, Thailand and Vietnam. Among the planned

113 dams in the Lower Mekong Basin, two located in Cambodia (Lower Sesan II dam) and Laos

114 (Xayaburi dam) have been recently approved for construction. Given that the majority of

115 Mekong River fishes are migratory with movements and spawning cued by the annual flood

116 pulse, these dams will have negative effects on aquatic communities by fragmenting rivers in the

117 longitudinal dimension, prohibiting colonization and community succession (Barlow et al. 2008;

118 Baran and Myschowoda 2008; Dugan et al. 2010). In addition, the existing and planned dams on

119 the mainstem of the Upper Mekong are predicted to trap at least $50 \%$ of the suspended sediment

120 load delivered to the Lower Mekong (Lu and Siew 2005; Kummu and Varis 2007), and dams

121 constructed within the lower basin will trap even more sediment, impacting the ecology of

122 segments in downstream countries (Kummu et al. 2010; Xue et al. 2010).

124 Study area 
This study was conducted in four large floodplain rivers in the Lower Mekong Basin in

126 Northeastern Cambodia: the Mekong, Sekong, Sesan and Srepok rivers. The Sekong, Srepok and

127 Sesan rivers (known as the 3S rivers) are the Lower Mekong's major tributaries that drain

128 northeastern Cambodia, southern Laos, and the central highlands of Vietnam. These rivers meet

129 the Mekong River mainstream at Stung Treng, a provincial capital in Cambodia. We sampled a

130 site on the Mekong River near Stung Treng (13.579383 N, 105.994366 E), the Sekong River at

131 Siem Pang (14.11434N, 106.39104E), the Sesan River at Veurn Sai (13.94585N, 106.79701E),

132 and the Srepok River at Lomphat (13.47508 N, 106.99683 E) (Fig. 1). Cambodia has a monsoon

133 climate with a six-month dry season (Nov-Apr) and six months of rain (May-Oct).

134 Five hundred fish species have been recorded from the Cambodian Mekong (Rainboth

135 1996). About $40 \mathrm{~km}$ of the Mekong River, from the Stung Treng-Kratie provincial border to near

136 the Cambodia-Laos border, and its riparian zone were designated as a RAMSAR wetland of

137 global significance because of its value for conservation of biodiversity in the Indo-Burma

138 region. Watersheds of the $3 \mathrm{~S}$ rivers have been recognized as critical areas for biodiversity

139 conservation because they contain high species diversity and dozens of endemic and endangered

140 species. Approximately 300 fish species, including at least 100 endemics and 14 endangered

141 species, have been recorded from the $3 \mathrm{~S}$ rivers (Baran et al. 2011).

142 There currently are over a dozen hydroelectric dams in operation on the Sesan River. The

143 largest, Yali Dam, is located upstream from our study site where there was a major waterfalls in

144 Vietnam, and blocks a formerly important fish migration route (Baran et al. 2011). A new dam,

145 Lower Sesan 2, has been approved for construction at a downstream site in Cambodia.

146 According to interviews with local residents, the Sesan's flow regime within our study reach is

147 strongly regulated by upstream dams, and the lack of large migratory fishes already has affected 
148 livelihoods of local people living along the river. Compared to the Sekong and Srepok, the Sesan

149 has lower flows and shallower water during the dry season (Baird and Meach 2005; Baran et al.

150 2011). The other two 3 S rivers currently have dams (Sekong-4, Srepok-24), but these are

151 smaller and located in headwaters $>100 \mathrm{~km}$ upstream from our study sites; consequently,

152 modifications of historic discharge patterns were not reported by local villagers. The Mekong

153 Basin currently has 371 dams, and nearly 100 new hydroelectric dams are planned (Winemiller

154 et al. 2016).

155

156 Sample collections and laboratory methods

157 To capture temporal variation of available basal production sources and aquatic

158 consumers, samples of algae, riparian macrophytes, and fishes were collected from each site

159 during both dry (Jan 2010, 2011) and wet seasons (July-Aug 2011). Interpretation of consumer

160 assimilation of production sources depends, in part, on isotopic turnover rates in tissues. In

161 fishes, tissue turnover is affected by several factors, including temperature, tissue type, body

162 size, and growth rate (Vander Zanden et al. 2015). According to a literature review, isotopic half-

163 life of fish muscle tissue averages about $25 \mathrm{~d}$, with a range 10-60 d (Boecklen et al. 2011). The

164 nitrogen isotopic half-life in muscle tissue of an herbivorous Neotropical catfish was estimated at

$16518.2 \mathrm{~d}$ (McIntyre and Flecker 2006) and the carbon isotopic half-life in muscle of Chinese grass

166 carp was $52.7 \mathrm{~d}$ (Xia et al. 2013). Because our samples were collected at least 3 mo after the

167 beginning each designated hydrologic season, we assume that muscle tissue $\mathrm{C}$ and $\mathrm{N}$ ratios

168 should largely reflect assimilation of in situ resources during the same season. Our assimilation

169 estimates would be biased if isotopic turnover actually was much slower than previously 
170 reported, or if there were major changes in isotopic ratios of sources that occurred several days 171 prior to collection of samples.

172 Attempts were made to collect the dominant (most obvious) basal production sources and

173 fish species at each site. Whenever possible, 3-5 individuals of each species were obtained from

174 each site. Different parts (leaves, fruits, seeds) of common riparian plants were collected, cut into

175 small pieces, placed in plastic bags and preserved in salt for later analysis in the laboratory.

176 Benthic algae samples (phytomicrobenthos) were collected by gently scraping rocks and

177 submerged tree branches. Seston samples (phytoplankton and other suspended organic matter)

178 were collected from near the water surface with 1-L opaque bottles, and water was filtered

179 through pre-combusted Whatman GF/F filters (pore size $0.7 \mu \mathrm{m}$ ) on which material was

180 collected. Fishes were collected during the dry and wet seasons using a seine net, cast net, and

181 dip net. Additional fish specimens were obtained from local fishers. Fish muscle tissue samples

182 were taken from the flank near the base of the dorsal fin. All samples were preserved in salt for

183 later analysis in the laboratory.

184 In the laboratory, tissue samples were soaked in distilled water for 4-5 hours, rinsed, and

185 dried in an oven at $60^{\circ} \mathrm{C}$ for 48 hours. After drying, samples were ground into fine powder using

186 an electronic ball-mill grinder. Subsamples were weighed to the nearest $0.02 \mathrm{mg}$ and packaged

187 into ultrapure tin capsules (follows methods of Arrington and Winemiller 2002). Samples were

188 analyzed for isotope ratios of carbon and nitrogen at the Analytical Chemistry Laboratory,

189 Institute of Ecology, University of Georgia, USA. During mass spectrometry, two different

190 standards were processed between every 12 tissue samples, and precision was $\pm 0.22 \%$ for $\delta^{13} \mathrm{C}$

191 and $\pm 0.20 \%$ for $\delta^{15} \mathrm{~N}$.

192 


\section{Stable isotope analysis}

We used stable isotopes of carbon and nitrogen to estimate production sources (algae and macrophytes) assimilated by fish in the four rivers. Stable isotopes of carbon and nitrogen have been widely used in estimating the relative importance of basal source contributions to metazoan food webs. Isotope ratios were reported in parts per thousand (\%o) standardized in relation to reference material (Pee Dee Belemnite for $\mathrm{C}$, atmospheric nitrogen for $\mathrm{N}$ ) and reported as $\delta X=$ $\left.\left[\left(R_{\text {sample }} / R_{\text {standard }}\right)-1\right)\right] * 10^{3}$, where $R={ }^{13} C /{ }^{12} C$ or ${ }^{15} N /{ }^{14} N$ (the ratio of heavy and light stable isotope of carbon or nitrogen).

Using PAST statistical software (Hammer et al. 2001), two-tailed t-tests were performed to test for seasonal differences in carbon and nitrogen stable isotope ratios of each major production sources within each river. To account for multiple comparisons with $\alpha=0.05$, the critical P was Bonferroni-corrected to 0.01. One-way ANOVA was performed to test for amongriver differences in carbon and nitrogen stable isotope ratios of production sources during each season.

\section{Mixing model}

MixSIR (Moore and Semmens 2008) was used to estimate the relative contribution of four alternative basal sources (seston, benthic algae, riparian $\mathrm{C}_{3}$ macrophytes, and riparian $\mathrm{C}_{4}$ grasses) to tissues of consumers. MixSIR uses a Bayesian framework that accounts for uncertainty associated with multiple sources and trophic fractionation (Woodland et al 2012).

We ran the model separately for each consumer species and for each season and site based on carbon and nitrogen isotope ratios of four major primary-production sources collected during the corresponding season and site. We did not correct consumer samples for lipids because C:N 
216 ratios were relatively low (mean $=3$ ). For the model input, we used a trophic fractionation value

217 of 2.5 for nitrogen (Vanderklift and Ponsard 2003) and 0.5 for carbon (McCutchan et al. 2003).

218 The Bayesian model yields probability distributions of feasible solutions, and we recorded the

219 median, 5\% and 95\% credible intervals for proportional contribution of each source to fish

220 biomass.

\section{Trophic guilds and habitat guilds classification}

To determine if functional groups assimilate production sources differentially, the mixing

224 model was run again for each site and season with species grouped into guilds. Trophic guilds

225 and habitat guilds were determined using information reported in Fishbase (2012) and Rainboth

226 (1996) as well as fish functional morphology. Fish trophic guilds were identified as: 1-Piscivore

227 if the fish consumes primarily fishes and sometimes smaller amounts of crustaceans or other

228 prey, 2-Omnivore if it consumes both zooplankton and phytoplankton, 3-Detritivore if it

229 consumes detritus and/or algae, and 4- Invertivore if it consumes invertebrates (i.e. aquatic

230 microcrustacea, macrocrustacea, aquatic insects, terrestrial arthropods) almost exclusively.

231 Habitat guilds were characterized by habitats where fish spend most of their time. Two habitat

232 guilds were identified: 1-River channel if adult size classes of the species were caught almost

233 exclusively from the river channel and local fishers confirmed that they generally catch them in

234 the channel, and 2-Floodplain if local fishers reported that adult size classes commonly are

235 caught in both river and floodplain habitats or nearly exclusively in the latter.

237 Results 
A total of 1087 individual fish and 109 primary production source samples were collected

239 during the study. Mean sample size for fish species per site was 2.43 (range 1-12); mean sample

240 size for production sources per site was 6.62 (range 5-8). Most of the fishes belong to the family

241 Cyprinidae, followed by Siluridae, Bagridae and Pangasidae. During the dry season, 699

242 individual fishes and 44 basal source samples were obtained for analysis. Seventy-one species

243 were obtained from the Mekong River near Stung Treng, 60 species from the Sekong, 31 species

244 from the Sesan, and 56 species from the Srepok. During this season, we collected $27(12 \%)$

245 detritivores, $80(36 \%)$ insectivores, 57 (26\%) omnivores, and $54(24 \%)$ piscivores from the

246 Mekong and 3S rivers (Table 1). During the wet season, water in the river channels was high and

247 swift and some fishes were dispersed in flooded riparian habitats. These conditions reduced

248 fishing success, and we collected 388 fish specimens and 65 basal production source samples

249 during the wet season, mostly near the edge of the river channel. Among fishes, 46 species were

250 collected from the Mekong, 31 species from the Sekong, 19 species from the Sesan, and 33

251 species from the Srepok. Compared to the dry season collection, the wet season survey yielded

252 fewer fish specimens within each trophic guild. Nonetheless, all trophic guilds were represented

253 with $17(13 \%)$ detritivores, $46(36 \%)$ insectivores, $49(38 \%)$ omnivores, and $16(12 \%)$

254 piscivores (Table 1).

255

256 Stable isotope signature of basal production sources

257 Except for seston and benthic algae samples collected during the wet season, the four 258 basal production sources (seston, benthic algae, $\mathrm{C}_{3}$ macrophytes, $\mathrm{C}_{4}$ grass) had little overlap in

$259 \delta^{13} \mathrm{C}$ values at each site during each season (Table 2, Fig. 2). In each of the four rivers, seston

260 and benthic algae revealed large seasonal differences in $\delta^{13} \mathrm{C}$ values (within-river seasonal shifts 
261 in mean $\delta^{13} \mathrm{C}$ of seston ranged from 10.4 to $13.0 \%$; benthic algae ranged from 16.5 to $20.3 \%$ ),

262 with both of these sources being significantly heavier during the dry season (Table 2, Fig. 2; t-

263 test of seasonal mean difference yielded $\mathrm{P}<0.01$ in each case, $\mathrm{t}-5.31-19.24$, df 5-8). Carbon

264 ratios of $\mathrm{C}_{3}$ macrophytes and $\mathrm{C}_{4}$ grass did not undergo significant seasonal shifts in any river.

$265 \delta^{15} \mathrm{~N}$ values of sources overlapped broadly and were not significantly different within or among

266 sites and seasons; however, $\mathrm{C}_{4}$ grass tended to have lower values compared to other sources

267 (Table 2, Fig. 2). Neither carbon nor nitrogen isotope ratios of any of the four sources differed

268 significantly among the four rivers during either season (ANOVA, $\mathrm{P} \geq 0.05$ in each case, $\mathrm{F}=$

$269 \quad 0.05-3.32$, df $3,6-17)$.

271 Stable isotope signature of fishes

272 Overall, average carbon isotopic signatures of fishes were relatively ${ }^{13} \mathrm{C}$ depleted during

273 the wet season compared to fishes collected during the dry season (Fig. 2). Most fishes had

274 carbon isotopic signature between the values of benthic algae and seston (but closer to seston)

275 during the dry season, and had carbon isotopic signature values closer to those of $\mathrm{C}_{3}$

276 macrophytes during the wet season (Fig. 2). In each river and season, the distribution of fish $\delta^{15} \mathrm{~N}$

277 values ranged approximately 7\%o, indicating nearly three trophic levels if one assumes an

278 average trophic fractionation for $\delta^{15} \mathrm{~N}$ of about 2.5\% (Vanderklift and Ponsard 2003).

280 Production source contributions

281 Isotopic differences between the four major primary production sources from each river

282 during each season, especially for carbon (Table 2), facilitated discrimination of material

283 assimilated by fishes. MixSIR estimated that seston and benthic algae were the principle sources 
284 contributing to fish biomass during the dry season (Fig. 3). Based on the $5^{\text {th }}$ percentile of the

285 probability distribution of feasible solutions, seston contributed over $10 \%$ to the biomass of more

286 than three fourths of the fishes across all four rivers (values were $>10 \%$ for all fishes in the

287 Sesan), and at the $95^{\text {th }}$ percentile, seston contributed greater than $50 \%$ to biomass for over half of

288 the fishes (Appendix 1). During the dry season, benthic algae contributed $>10 \%$ to biomass for

289 about $40 \%$ of fishes (and nearly three fourths of Sesan fishes) based on the $5^{\text {th }}$ percentile

290 estimate, and at the $95^{\text {th }}$ percentile, the contribution of benthic algae was estimated at $31-60 \%$ for

291 more than half of the fishes. At the $5^{\text {th }}$ percentile, the estimated contribution of riparian $\mathrm{C}_{3}$

292 macrophytes to consumer biomass was $<10 \%$ for about $60 \%$ of fishes ( $80 \%$ of Sesan fishes),

293 and at $95^{\text {th }}$ percentile, $C_{3}$ macrophytes contributed $31-70 \%$ to biomass of most fishes during the

294 dry season. Riparian $\mathrm{C}_{4}$ grass had $5^{\text {th }}$ percentile estimates of $<10 \%$ biomass contribution for 295 more than $90 \%$ of fishes across all four rivers.

296 Model estimates for the wet season indicated that riparian $\mathrm{C}_{3}$ macrophytes were the

297 dominant basal production source supporting trophic pathways to fishes, and benthic algae were

298 the least important for fishes in all four rivers (Fig. 4). At the $5^{\text {th }}$ percentile, estimated

299 contribution of benthic algae to fish biomass was $<10 \%$ in all cases, and estimates for seston

300 were $<10 \%$ for over $90 \%$ of fishes (Appendix 1 ). At the $5^{\text {th }}$ percentile, riparian $C_{3}$ plants had

301 estimated contributions to fish biomass $>20 \%$ for most species in the four rivers, and at the $95^{\text {th }}$

302 percentile, estimated contributions of $\mathrm{C}_{3}$ plants for most fishes were $>60 \%$. During the wet

303 season, riparian $\mathrm{C}_{4}$ grasses contributed $<10 \%$ to biomass of more than half of the fishes based on

304 the $5^{\text {th }}$ percentile estimate, and $21-50 \%$ for most fishes based on the $95^{\text {th }}$ percentile estimate.

305 Model estimates revealed some differences in proportional contributions of primary

306 production sources to the four trophic guilds during the dry season, but few differences during 
307 the wet season (Appendix 2). Benthic algae had the greatest proportional contribution to

308 detritivore biomass during the dry season (e.g. Gyrinocheilus pennocki, Mekongina erythrospila,

309 Morulius chrysophekadion), between $30\left(5^{\text {th }}\right.$ percentile $)$ and 60 (95 $5^{\text {th }}$ percentile $)$ percent.

310 Estimated proportional contributions of seston and $\mathrm{C}_{3}$ macrophytes to biomass of insectivorous

311 fishes (e.g. Cyclocheilichthys and Micronema spp.) were large compared to estimates for benthic

312 algae and $\mathrm{C}_{4}$ grass. During the dry season, omnivores (e.g. several pangasids) and piscivores

313 (e.g. Channa, Chitala, Wallago) probably assimilated carbon originating from multiple sources,

314 including seston, benthic algae, $\mathrm{C}_{3}$ macrophytes and a minor fraction of $\mathrm{C}_{4}$ grasses. All sources

315 except $\mathrm{C}_{4}$ grasses had estimated contributions to omnivores and piscivores $>10 \%$ at the $5^{\text {th }}$

316 percentile and $>40 \%$ at the $95^{\text {th }}$ percentile (Fig. 5).

317 Estimates of source contributions differed between fishes that are largely restricted to the

318 river channel and fishes commonly found in floodplain habitats. $\mathrm{C}_{3}$ plants apparently made

319 greater contribution to biomass of fishes that inhabit floodplain habitats, with estimates ranging

320 from $13-50 \%$, compared to their estimated contributions to fishes inhabiting river channels that

321 ranged from 1-44\% (Appendices). Although riparian $\mathrm{C}_{4}$ grasses had low estimated contributions

322 to fish biomass during the dry season, these plants may have contributed to biomass of certain

323 species, especially air-breathing fishes, during the wet season and to some extent during the dry

324 season (Appendices). Fishes possessing aerial respiratory adaptations commonly inhabit

325 floodplain pools; species in this group include clariid catfishes (Clarias batrachus, C.

326 macrocephalus, C. melanoderma), snakeheads (Channa limbata, C. lucius, C. marulioides, C.

327 micropeltes, C. striata), and labyrinth fish (Pristolepis fasciata).

329 Discussion 


\section{Seasonal patterns}

Carbon stable isotope signatures of benthic algae and seston in our study were much

332 lower during the wet season compared to values obtained in the dry season. This variation can be

333 influenced by differences in watershed geochemistry, variation among sources of inorganic

334 carbon, differential diffusion rates of ${ }^{13} \mathrm{C}$ and ${ }^{12} \mathrm{C}$ during photosynthesis under varying

335 environmental conditions, water velocity outside the cell walls, and availability of dissolved

336 inorganic carbon (DIC) from various pools (Finlay et al. 1999; Finlay 2001, 2004). MacLeod and

337 Barton (1998) found that enriched $\delta^{13} \mathrm{C}$ corresponds to higher rates of photosynthesis. Carbon

338 stable isotope ratios of algae have been shown to vary in association with climatic conditions and

339 river discharge (Forsberg et al 1988; Hamilton et al. 1992; Hamilton and Lewis 1992; Depetris

340 and Kempe 1993; Hecky and Hesslein 1995). A meta-analysis of carbon stable isotope ratios of

341 lotic periphyton indicated that water current velocity, canopy cover, and chlorophyll $a$ density

342 affect $\delta^{13} \mathrm{C}$, with values also varying among taxonomic groups (Ishikawa et al. 2012). That study

343 also reported large seasonal shifts of periphyton $\delta^{13} \mathrm{C}$ in tropical lotic systems.

344 Our findings indicate that most fish species in each of the four Lower Mekong rivers had

345 assimilated variable mixtures of basal production sources collected from the study sites.

346 However, the most striking pattern was that, in all four rivers, there was a seasonal shift in the

347 major basal production source supporting fish biomass. During the dry season, fish biomass

348 appears to derive mostly from algae, and during the wet season $\mathrm{C}_{3}$ macrophytes appear to be the

349 most important source supporting fish biomass overall. These differences in relative

350 contributions of basal production sources to fish biomass probably reflect seasonal availability of

351 alternative sources in these rivers. An investigation of seasonal variability in sources of

352 particulate organic matter of the Lower Mekong River in Cambodia using elemental and lignin 
353 analysis (Ellis et al. 2012) found that fine particulate organic matter (FPOM) was dominated by

354 autochthonous sources (derived from phytoplankton) during the dry season. During the wet 355 season, a greater proportion of FPOM was derived from vascular plants.

356 During periods of low flow in large rivers, ambient nutrient concentrations often are

357 higher, water transparency increases, and productivity of algae increases (Kirk 1985; Montoya et

358 al. 2006; Roach 2013). Several investigators have suggested that algae provide better nutrition

359 and contain more digestible components compared to macrophyte tissues, much of which can be

360 highly refractory (Sarkanen and Ludwig 1971; Renaud et al. 1999; Cotner and Biddanda 2002).

361 Therefore, algae should enter grazer food chains efficiently (Thorp and Delong 1994; Delong

362 and Thorp 2006). Several studies found that algae are an important production source supporting

363 aquatic consumers during low-flow periods (e.g. Lewis 1988; Hamiliton et al. 1992; Forsberg et

364 al. 1993; Zeug and Winemiller 2008). A study in the Tonle Sap, the great lake of Cambodia that

365 connects to the Mekong River, also concluded that algal production, rather than terrestrial

366 organic material, was the major source supporting fish biomass during the annual low-water

367 period (Campbell et al. 2009). Roach (2013) postulated that this pattern in rivers depends on soil

368 characteristics and the degree to which flood pulses increase suspension of fine sediments that

369 increase turbidity and reduce light penetration. Such conditions normally occur in rivers of the

370 Lower Mekong Basin during the wet season.

371 In all four rivers, allochthonous production sources were estimated to be the most

372 important sources supporting fish biomass during the wet season when flows were high and

373 floodplains inundated. During the wet season, algal production probably declines due to scouring

374 of substrates, suspension of fine sediments, increased turbidity, and reduced light penetration

375 (Wissmar et al. 1981; Roach 2013). Although many $\mathrm{C}_{3}$ plants in the tropics have relatively low 
376 nutritional value and also contain secondary chemical compounds that deter herbivory, they can

377 become more nutritious following partial decomposition by bacteria and fungi that increases

378 availability of nitrogen-rich material and causes leaching of defense compounds (Caraco et al.

379 1998; Davis et al. 2006). It also has been suggested that the high incidence of herbivory among

380 fishes in the tropics may have evolved in response to seasonal availability of plant material,

381 especially seeds and fruits, in seasonally flooded forests (Lowe-McConnell 1975; Goulding

382 1980; Correa et al. 2007; Correa and Winemiller 2013). Many fishes in the tropical rivers have

383 physiological and morphological adaptations to feed on detritus or plant material (Goulding et al.

384 1988; Horn et al. 2011). It has been hypothesized that some plants species have coevolved with

385 fish to release their seeds during floods so that fishes can consume and disperse them. In the

386 Neotropics, several species of herbivorous fishes feed extensively on fruits, flowers, and seeds

387 (Lowe-McConnell 1975; Goulding 1980; Correa et al. 2007; Horn et al. 2011). Leptobarbus

388 hoevenii, Mekongina erythrospila, Osphronemus goramy, O. exodon, and several other Mekong

389 fishes are reported to enter flooded forests to feed on fruits (Rainboth 1996). A few studies of

390 temperate-zone rivers also have found that terrestrial carbon is an important source supporting

391 aquatic consumers during high-flow pulses (Huryn et al. 2001; Zeug and Winemiller 2008), but

392 it is likely that this material is not being consumed by fishes directly, because comparatively few

393 temperate-zone fishes possess morphological traits indicative of granivory or frugivory (Correa

394 et al. 2007; Horn et al. 2011).

395 The present study was conducted in rivers that experience extensive flooding during the 396 wet season each year (duration $\sim 6$ months). Annual flood pulses of large tropical rivers provide

397 fishes with access to both terrestrial and aquatic food resources in floodplains (Lowe-McConnell

398 1969; Goulding 1980; Junk et al. 1989), and this seems to explain the high secondary 
399 productivity that supports major fisheries in these systems (Welcomme 1979; Goulding et al.

400 1988; Correa and Winemiller 2013). During annual flood pulses in the tropics, submerged

401 riparian vegetation is consumed by herbivorous invertebrates and fishes that, in turn, are

402 consumed by predatory fishes. During the flood pulse, fishes have greater access to terrestrial

403 arthropods. Long flood duration also promotes decomposition of submerged terrestrial

404 vegetation (Balcome et al 2005; Rayner et al. 2010). Detritivorous fishes can then exploit the

405 nutritious microbial biomass associated with decomposing submerged vegetation (Bowen et al.

406 1984; German et al. 2010; Lujan et al. 2011).

407 Studies also indicate that aquatic consumers mostly assimilate carbon derived from $\mathrm{C}_{3}$

408 plants and little from $\mathrm{C}_{4}$ plants (Thorp et al. 1998; Zeug and Winemiller 2008; Roach et al.

409 2009). In our study, fishes from all four rivers appeared to assimilate little carbon from $\mathrm{C}_{4}$

410 grasses compared to $\mathrm{C}_{3}$ plants, and this was the case during both seasons. This is not surprising

411 considering that these grasses generally have relatively low nutritional value compared to most

$412 \mathrm{C}_{3}$ macrophytes, and much less compared to algae. $\mathrm{C}_{4}$ grass tissues contain compounds, such as

413 hemicelluloses, cellulose and lignin, that are difficult for most animals to digest (Minson 1971).

414 Nevertheless, $\mathrm{C}_{4}$ grasses can be broken down by microbes and subsequently buried in sediments

415 before entering the upper food web by way of organisms consuming detritus that has been

416 processed through the microbial loop (Cole et al. 2011). Only a few studies (Forsberg et al. 1993;

417 Jepsen and Winemiller 2007) have inferred significant assimilation of $\mathrm{C}_{4}$ grasses by certain

418 fishes, for example, Schizodon fasciatus from the Amazon River in Brazil and S. isognatus from

419 the Apure River in Venezuela. The present study indicates that $\mathrm{C}_{4}$ grasses could a source in food

420 chains leading to certain groups of fishes, such as air-breathing fishes (Channa and Clarias) that

421 commonly inhabit floodplain pools and swamps. This is consistent with a recent study in the 
422 Oueme River in West Africa that concluded air-breathing fishes from man-made ponds in the

423 floodplain had assimilated variable amounts of carbon from $\mathrm{C}_{4}$ grasses (Jackson et al. 2013).

425 Production sources supporting guilds

426 Estimates of basal production sources supporting fishes grouped according to trophic and

427 habitat guilds revealed some general trends, especially during the dry season. Detritivores and

428 algivores apparently had assimilated large fractions of material derived from benthic algae.

429 Given that these fishes scrape or suck organic materials from substrates, they should have carbon

430 stable isotope signatures that reflect values obtained for bulk samples of benthic

431 microphytobenthos (referenced in this study as benthic algae, but perhaps also containing

432 microorganisms and organic matter of allochthonous origin). Most fishes classified as

433 insectivores apparently had assimilated material derived mostly from a single basal source, either

434 seston or $\mathrm{C}_{3}$ plants. Fishes classified here as insectivores probably feed mostly on aquatic insect

435 larvae, microcrustacea, and other aquatic invertebrates that consume some combination of algae

436 and detritus derived from both autochthonous and allochthonous sources. MixSIR model

437 estimates indicate that piscivores and omnivores likely had assimilated material from multiple

438 basal sources, including benthic algae, seston, $\mathrm{C}_{3}$ plants and, to a much lesser extent, $\mathrm{C}_{4}$ plants.

439 These findings suggest that piscivores and omnivores assimilate material derived from diverse

440 trophic pathways. Studies from other tropical river systems indicated that omnivory is

441 widespread among fishes (Winemiller 1990; Polis et al. 1996), and many fishes of the Mekong

442 have been classified as omnivores (Rainboth 1996).

443 Estimates of production sources assimilated by fishes in the two habitat guilds were

444 different during the dry season, but not during the wet season. For fishes that are largely 
445 restricted to the river channel, algae apparently made a greater contribution to fish biomass

446 during the dry season, whereas $C_{3}$ macrophytes had relatively greater importance for fishes that

447 typically inhabit floodplain habitats. Previous studies also found that fish inhabiting channel

448 habitats are strongly supported by trophic pathways originating from algae (e.g. Forsberg et al.

449 1993; Lewis et al. 2001; Roach et al. 2009). Most channel-dwelling fishes in the Lower Mekong

450 River show this pattern; however, a few species of loaches (e.g. Acanthopsis and Schistura spp.)

451 could have assimilated significant material originating from macrophytes. These loaches

452 probably consume microcrustacea and other tiny aquatic invertebrates that consume detritus or

453 microorganisms that process macrophyte detritus despite its refractory nature (Caraco et al.

454 1998; Davis et al. 2006). Food web research on tropical streams in Hong Kong that employed

455 analyses of gut contents and stable isotopes found that loaches (Balitoridae) consumed and 456 assimilated bacteria (Lau et al. 2009a, 2009b).

457 Previous research has estimated that most fishes inhabiting floodplain habitats are 458 supported by trophic pathways originating from macrophytes as well as pathways that originate 459 from algae (Rai and Hill 1984; Zeug and Winemiller 2008; Jackson et al. 2013). In our study, 460 air-breathing fishes, such as Channa (Channidae) and Clarias (Clariidae) species, that often 461 inhabit floodplain habitats, support this observation. These species apparently assimilate 462 significant amounts of material derived from algae and macrophytes. A recent study in West 463 Africa similarly concluded that air-breathing fishes from these families from floodplain habitats 464 were supported by both macrophytes and microphytobenthos but not seston (Jackson et al.

465 2013). Shallow aquatic habitats in tropical river floodplains often are covered with dense mats of 466 floating macrophytes that can reduce gas exchange at the surface and block light penetration in 467 the water column and thereby hindering algal production. Despite low water-column 
468 productivity, consumers in these habitats may assimilate material originating from epiphytic

469 algae that may have low standing biomass but high turnover (Jackson et al. 2013). For example,

470 Bunn et al. (2003) estimated that benthic algae was the principal production source supporting

471 aquatic consumers of the Cooper Creek floodplain in central Australia. Likewise, Hamilton et al.

472 (1992) found that algal production supports most of the biomass of fish assemblages in lagoons

473 within the floodplains of the lower Orinoco River in Venezuela.

474

475 River impoundment

476 Because the hydrology of the Sesan River is impacted by the Yali Dam in Vietnam, we

477 anticipated that its fish assemblage and food web might differ from the other three rivers. Dams

478 are barriers to longitudinal fish movement (Dugan et al. 2010), and the Mekong Basin contains

479 many migratory species, some of which move hundreds of kilometers on a seasonal basis

480 (Barlow et al. 2008; Baran and Myschowoda 2008). Fish species richness of our Sesan samples

481 (32 dry, 19 wet) was much lower compared to the other rivers (55-71 dry, 31-45 wet). During the

482 dry season, we obtained few pangasids (migratory fishes) in the Sesan compared to the other

483 three rivers that are less impacted by dams. A review by Baran et al. (2011) found that the Sesan

484 currently has far fewer migratory fishes compared to other Mekong tributaries, including the

485 Sekong and Srepok rivers. Their study revealed that a number of migratory species, particularly

486 those belonging to the Pangasidae (e.g. Pangasius conchophilus), have declined in the Sesan

487 (Baran et al. 2011). Similarly, Hoeinghaus et al. (2009) found that creation of the Itaipu

488 Reservoir on the Paraná River in Brazil created a barrier to fish migration and altered the fish

489 assemblage and fishery. Dams also have been demonstrated to have strong effects on fish

490 community composition by favoring equilibrium strategists while adversely affecting 
491 populations of periodic and opportunistic strategists (Mims and Olden 2013). Proportions of 492 species in various trophic guilds was very similar among the three relatively unimpacted rivers, 493 but different for the Sesan (fewer detritivores and piscivores during both seasons, more 494 insectivores during the dry season; Table 1). By altering hydrology, dams also can affect food web ecology, including the seasonal 496 availability of basal production sources and their contributions to fish biomass. Isotopic 497 signatures of the four basal production sources in the Sesan were very similar to those in the 498 other three rivers during each season. Estimates from the mixing model indicated that seston and 499 benthic algae were the most important sources supporting food webs of all four rivers during the 500 dry season, and estimates for the Sesan were highest. Local fishers from the village of Veurn Sai 501 reported to us that reduced water discharge following construction of the Yali Dam had reduced 502 substrate scouring and maintenance of deep pool habitat for fish. Reduced discharge also could 503 have reduced sediment suspension, especially during the dry season, which might enhance algal 504 production. A study conducted in rivers of the Paraná Basin in Brazil (Hoeinghaus et al. 2007) 505 concluded that consumers inhabiting river reaches below impoundments are more dependent on 506 algal production compared to reaches above the same impoundments. That study hypothesized 507 that dams trap sediments, thereby increasing water transparency in tailwaters that allows greater 508 light penetrance and algae growth. Dams in the Lower Mekong Basin have been estimated to 509 trap more than 50\% of suspended sediment load (Kummu et al. 2010; Xue et al. 2010).

$510 \quad$ Our study also indicates that there is less contribution of $\mathrm{C}_{3}$ macrophytes to fish biomass 511 in the Sesan River compared to the other rivers. This might be due to a reduced annual flood 512 pulse and more restricted access to floodplain habitats for migratory fishes. Most (85-90\%) of 513 the Mekong Basin's discharge occurs during the monsoon season. However, as a result of dam 
514 operations, water levels in some tributaries of Mekong have declined in recent years (Zalinge et

515 al. 2000; Lu and Siew 2005). This was especially apparent in the Sesan River during the dry

516 season in 2010-2011, when discharge was very low compared to the other two tributary rivers.

518 Fish migration, isotopic ratios and tissue turnover

Migratory fishes are important components of river food webs because they assimilate

520 and transport primary and secondary production as they move from one landscape unit to

521 another. They subsidize river food webs by enhancing the resource base for apex predators (Polis

522 et al.1997; Winemiller and Jepsen 1998; Horn et al. 2011). Winemiller and Jepsen (1998)

523 proposed that fish migrations in tropical rivers are a response to spatial and temporal

524 environmental variation, especially with regard to food resource availability and

525 physicochemical factors such as dissolved oxygen.

526 A potential limitation of our study is that some Mekong fishes are migratory and

527 therefore could have previously consumed and assimilated food resources from locations distant

528 from the study sites where they were captured (e.g. locations upstream or downstream, or

529 seasonal floodplain habitats). In addition, small migratory fishes that are prey for other fishes

530 could have assimilated and transported material derived from sources at distant locations, and

531 thereby imported it into food webs at the study locations (Polis et al. 1996; Winemiller and

532 Jepsen 1998). Thus, it cannot be ruled out that some fishes might have migrated into the study

533 areas with isotopic signatures derived from feeding at distant locations (Polis et al. 1996). A

534 recent study of Australian tropical rivers demonstrated that a river having floodplain inundation

535 of long duration revealed a weak relationship between isotopic signature of fishes and local

536 sources (biofilm), whereas the river with a short flood period showed a stronger relationship 
537 between isotopic composition of fishes and in-situ resources (Jardine et al. 2012). Considering

538 fish tissue turnover rate, ( 1-3 months for muscle tissue, Buchheister and Latour 2010), our

539 study design and interpretations should not be greatly influenced by recent arrival of migratory

540 fishes that had assimilated sources from outside the location where they were caught. Our

541 sampling was conducted in the middle of each season (3-4 months after the start of each season),

542 which should have allowed enough time for stable isotope ratios of fish muscle tissues to reflect

543 consumption and assimilation of local food resources. In tropical rivers, major fish migrations

544 generally occur near the onset of the annual flood pulse, and again during the early phase of

545 flood recession (Lowe-McConnell 1975; Goulding 1980). Therefore, it seems likely that muscle

546 tissue of migratory species within our dataset reflected, to a large extent, assimilation of local

547 food sources.

549 Conclusion

550 Our study revealed the importance of temporal variation of the flood pulse and

551 availability of alternative primary production sources for fish stocks of the Lower Mekong River.

552 Algae appear to be the most important production source supporting fish biomass during the dry

553 season when water discharge is low and transparency is high, and riparian macrophytes are the

554 most important production source supporting fishes during the wet season when discharge is

555 high and water is turbid. Many studies of tropical river food webs have shown spatial rather than

556 temporal variation, largely because they only collected samples from multiple rivers during a

557 restricted period (e.g. Hoeinghaus et al. 2007, 2008, 2009; Roach et al. 2009; Jardine et al. 2012).

558 Our findings stress the need for more detailed studies of seasonal variation in food web structure 
559 and function in rivers, especially in tropical regions where seasonal flooding is often pronounced 560 and prolonged.

561 Our study not only adds to the body of evidence that food web dynamics in tropical rivers 562 undergo significant seasonal shifts, but also emphasizes that river food webs are altered by dams 563 and flow regulation. The findings emphasize the need for more evaluation of ecological impacts

564 of hydropower development in the region (Dugan et al. 2010). The Yali Dam on the upper Sesan

565 River has changed hydrology in the lower reaches, which, according to local fishers, has

566 impacted river geomorphology and migratory fish stocks in the reach near Veurn Sai. The impact

567 of dams on ecosystem functions, biodiversity, and human populations in the Lower Mekong

568 Basin is potentially large and irreversible. Given that riparian vegetation appears to play a large

569 role in supporting fish production in the Lower Mekong and 3S rivers, particularly during the

570 wet season, there is an urgent need for further research of potential impacts from dams and

571 deforestation in this region.

572

573

574 Acknowledgements

575 We are grateful local fishers and villagers of Thmei, Seim Pang, Veurn Sai, and Lomphat of

576 Cambodia for help in catching fish. We thank collaborators at the Inland Fisheries Research and

577 Development Institute of Cambodia, especially Nam So for providing the permits and Putrea

578 Solyda for help in the field and with translations of local dialects. We also thank Katie Roach for

579 reading and providing feedback on the manuscript. Funding for this project was provided by the

580 Estate of Carolyn and George Kelso via the International Sport Fish Fund at Texas A\&M

581 University.

582 
583

584

585

586

587

588

589

590

591

592

593

594

595

596

597

598

599

600

601

602

603

604

605

606

\section{References}

Adamson, P. T., Rutherfurd, I. D., Peel, M. C., and Conlan, I. A . 2009. The hydrology of the Mekong River. In the Mekong biophysical environment of an international river basin. Edited by I.C. Campbell. Academic Press, New York. pp. 53-76.

Agostinho, A.A., Pelicice, F.M., and Gomes, L.C. 2008. Dams and the fish fauna of the Neotropical region: impacts and management related to diversity and fisheries. Braz. J. Biol. 68: 1119-1132.

Arrington, D. A., and Winemiller, K. O. 2002. Preservation effects on stable isotope analysis of fish muscle. Trans. Am. Fish. Soc. 131: 337-342.

Baird, I.G., and Meach, M. 2005. Sesan River fisheries monitoring in Ratanakiri province, northeast Cambodia: before and after construction of the Yali Falls dam in the Central Highlands of Vietnam. 3S Rivers Protection Network and the Global Association for the People and the Environment. Ratanakiri, Ban Lung.

Balcombe, S.R., Bunn, S.E., McKenzie-Smith, F.J., and Davies, P.M. 2005. Variability of fish diets between dry and flood periods in an arid zone floodplain river. J. Fish Biol. 67: $1552-1567$.

Baran E., and Myschowoda, C. 2008. Have fish catches been declining in the Mekong river basin? In Modern myths of the Mekong-part II: Making living out of nature. Edited by M. Kummu, M., Keskinen, and O. Varis. Water and Development PublicationsHelsinski University of Technology, Helsinski. pp.55-67.

Baran, E., Saray, S., Teoh, S.J., and Tran, T.C. 2011. Fish and fisheries in the Sesan River BasinCatchment baseline, fisheries section. Mekong Challenge Program project MK3 "Optimizing the management of a cascade of reservorirs at the catchment level". WorldFish Center, Phnom Penh. 
607

608

609

610

611

612

613

614

615

616

617

618

619

620

621

622

623

624

625

626

627

628

629

Barlow, C., Baran, E., Halls, A., and Kshatriya, M. 2008. How much of the Mekong fish catch is at risk from mainstem dam development? Mekong River Commission, Vientiane. pp 1621.

Boecklen, W.J., Yarnes, C.T., Cook, B.A., and James, A.C. 2011. On the use of stable isotopes in trophic ecology. Annu. Rev. Ecol. Syst. 42: 411-440.

Bowen, S.H., Bonetto, A.A., and Ahlgren, M.O. 1984. Microorganisms and detritus in the diet of a typical neotropical riverine detritivore, Prochilodus platensis (Pisces: Prochilodontidae). Limnol. Oceanogr. 29: 1120-1122.

Bunn, S.E., and Arthington, A.H. 2002. Basic principles and ecological consequences of altered flow regimes for aquatic biodiversity. J. Environ. Manage. 30: 492-507.

Bunn, S.E., Davies, P.M., and Winning, M. 2003. Sources of organic carbon supporting the food web of an arid zone floodplain river. Freshwater Biol. 48: 619-635.

Campbell, I.C., Say,S., and Beardall, J. 2009. Tonle Sap Lake, the heart of the Lower Mekong. In The Mekong biophysical environment of an international river basin. Edited by I.C. Campbell. Academic Press, New York. pp. 251-272.

Caraco, N.F., Lampman, G., Cole, J.J., Limburg, K.E., Pace, M.L., and Fischer, D.1998. Microbial assimilation of DIN in a nitrogen-rich estuary: implications for food quality and isotope studies. Mar. Ecol.: Prog. Ser. 167: 59-71.

Cole, J.J., Carpenter, S.R., Kitchell, J., Pace, M.L., Solomon, C.T., and Weidel, B. 2011. Strong evidence for terrestrial support of zooplankton in small lakes based on stable isotopes of carbon, nitrogen, and hydrogen. Proc. Natl. Acad. Sci. 108:1975-1980.

Correa, S.B., Winemiller, K.O., López-Fernández, H., and Galetti, M. 2007. Evolutionary perspectives on seed consumption and dispersal by fishes. BioScience 57: 748-756. 
630 Correa, S.B., and Winemiller K.O. 2013. Niche partitioning among frugivorous fishes in response to fluctuating resources in the Amazonian floodplain forest. Ecology 95: 210-224.

632 Cotner, J.B., and Biddanada, B.A. 2002. Small players, large role: microbial influence on 633 biogeochemical processes in pelagic aquatic ecosystems. Ecosystems 5: 105-121.

634 Davis, S.E. III, Childers, D.L., and Noe, G.B. 2006. The contribution of leaching to the rapid release of nutrients and carbon in the early decay of wetland vegetation. Hydrobiologia 569: $87-97$.

Delong, M.D., and Thorp, J.H. 2006. Significance of instream autotrophs in trophic dynamics of the Upper Mississippi River. Oecologia 147: 76-85.

Depetris, P.J., and Kempe, S. 1993. Carbon dynamics and sources in the Parana River. Limnol. Oceanogr. 38: 382-395.

Dudgeon, D. 2000. Large-scale hydrological alterations in tropical Asia: prospects for riverine

\section{3} biodiversity. BioScience 50: 793-806.

Dudgeon, D. 2010. Requiem for a river: Extinctions, climate change and the last of the Yangtze. Aquat. Conserv. : Mar. Freshwater Ecosys. 20: 127-131.

Dudgeon, D., Cheung, F.K.W., and Mantel, S.K. 2010. Food web structure in small streams: do we need different models for the tropics? J. N. Am. Benthol. Soc. 29: 395-412.

Dugan P.J., Barlow, C., Agostinho, A.A., Baran, E., Cada, G.F., Chen, D., Cowx, I.G., Ferguson, J.W., Jutagate, T., Mallen-Cooper, M., Marmulla, G., Nestler, J., Petrere, M., Welcomme, R.L., and Winemiller, K.O. 2010. Fish Migration, Dams, and loss of ecosystem services in the Mekong Basin. Ambio 39: 344-348. 
651 Ellis, E.E., Keil, R.G., Ingalls, A.E., Richey, J.E., and Alin, S.R. 2012. Seasonal variability in the sources of particulate organic matter of the Mekong River as discerned by elemental and lignin analyses. J. Geohys Res., B 117: 1-15. DOI: 10.1029/2011JG001816

654 Finlay, J.C., Power, M.E., and Cabana, G. 1999. Effects of water velocity on algal carbon isotope ratios: implications for river food web studies. Limnol. Oceanogr. 44: 1198-1203.

656 Finlay, J.C. 2001. Stable-carbon-isotope ratios of river biota: Implications for energy flow in lotic food webs. Ecology 82: 1052-1064.

658 Finlay, J.C. 2004. Patterns and controls of lotic algal stable carbon isotope ratios. Limnol. Oceanogr. 49: 850-861.

Forsberg, B.R., Araujo-Lima, C.A.R.M., Martinelli, L.A., Victoria, R.L., and Bonassi, J.A. 1993. Autotrophic carbon sources for fish of the central Amazon. Ecology 74: 643-652.

663 German, D.P., Neuberger, D.T., Callahan, M.N., Lizardo, N.R., and Evans, D.H. 2010. Feast to famine: the effects of food quality and quantify on the gut structure and function of a

666 Goulding, M.1980. The Fishes and the Forest: Explorations in Amazonian Natural History. University California Press, Berkeley, CA.

668 Goulding, M., Carvalho, M.L., and Ferreira, E.G. 1988. Rio Negro, rich life in poor water: Amazonian diversity and food chain ecology as seen through fish communities. SPB Academic Publishing, The Hague, The Netherlands.

671 Grumbine, R.E., Dore, J., and Xu, J. 2012. Mekong hydropower: drivers of change and governance challenges. Front. Ecol. Environ. 10: 91-98. 
673 Hamilton, S.K., Lewis, W.M. Jr., and Sippel, S.J. 1992. Energy sources for aquatic animals in 674 the Orinoco river floodplain: evidence from stable isotope. Oecologia 89: 324-330.

675 Hammer, O., Harper, D.A.T., and Ryan, P.D. 2001. PAST: Paleontological statistics software package for education and data analysis. Palaeontologia Electronica 4: 1-9.

677 Hecky, R.E., and Hesslein, R.H. 1995. Contributions of benthic algae to lake food webs as revealed by stable isotope analysis. J. N. Am. Benthol. Soc. 14: 631-653.

679

680

681

682

683

684

685

686

687

688

689

690

691

692

693

694

Hoeinghaus, D.J., Winemiller, K.O., and Agostinho, A.A. 2007. Landscape-scale hydrologic characteristics differentiate patterns of carbon flow in large river food webs. Ecosystems 10: $1019-1033$.

Hoeinghaus, D.J., Winemiller, K.O., and Agostinho, A.A. 2008. Hydrogeomorphology and river impoundment affect food-chain length in diverse Neotropical food webs. Oikos 117: 984995.

Hoeinghaus, D.J., Agostinho, A.A., Gomes, L.C., Pelicice, F.M., Okada, E.K., Latini, J.D., Kashiwaqui, E.A.L., and Winemiller, K.O. 2009. Effects of river impoundments on ecosystem services of large tropical rivers: embodied energy and market value of artisanal fisheries. Conserv. Biol. 23: 1222-1231.

Horn, M. H., Correa, S. B., Parolin, P., Pollux, B. J. A., Anderson, J. T., Lucas, C., Widmann, P., Tjiu, A., Galetti, M., and Goulding, M. 2011. Seed dispersal by fishes in tropical and temperate fresh waters: the growing evidence. Acta Oecologica 37: 561-577.

Huryn, A.D., Riley, R.H., Young, R.G., Arbuckle, C.J., Peacock, K., and Lyons, G. 2001. Temporal shift in the contribution of terrestrial organic matter to consumer production in a grassland river. Freshwater. Biol. 46: 213-226. 
695 Ishikawa, N.F., Doi, H., and Finlay, J.C. 2012. Global meta-analysis for controlling factors on 696 carbon isotope ratios of lotic periphyton. Oecologia 170: 541-549.

697 Jackson, A.T., Adite, A., Roach, K.A., and Winemiller, K.O. 2013. Primary production, food web structure, and fish yields in constructed and natural wetlands in the floodplain of an African river. Can. J. Fish. Aquat. Sci. 70: 543-553.

Jardine, T.D., Pettit, N.E., Warfe, D.M., Pusey, B.J., Ward, D.P., Douglas, M.M., Davies, P.M., and Bunn, S.E. 2012. Consumer-resource coupling in wet-dry tropical rivers. J. Anim. Ecol. 81: 310-322.

Jardine, T.D., Bond, N.R., Burford, M.A., Kennard, M.J., Ward, D.P., Baylis, P., Davies, P.M., Douglas, M.M., Hamilton, S.K., Melack, J.M., Naiman, R.J., Petitt, N.E., Pusey, B.J., Warfe, D.M., and Bunn, S.E. 2015. Does flood rhythm drive ecosystem responses in tropical riverscapes? Ecology 96: 684-692.

Jepsen, D.B, and Winemiller, K.O. 2007. Basin geochemistry and isotopic ratios of fishes and basal production sources in four Neotropical rivers. Ecol. Freshw. Fish 16: 267-281.

Junk, W.J., Bayley, P.B, and Sparks, R.E. 1989. The flood pulse concept in river-floodplain systems. In Proceedings of the International Large River Symposium (LARS), 14-21 September 1986. Canadian special publication of fisheries and aquatic sciences number 106. Department of fisheries and oceans, Ottawa, Ontario, pp. 110-127.

713 Kirk, J.T.O. 1985. Effects of suspensoids (turbidity) on penetration of solar radiation in aquatic ecosystems. Hydrobiologia 125: 195-208.

715 Kondolf, G.M., Rubin, Z.K., and Minear, J.T. 2014. Dams on the Mekong: Cumulative sediment starvation. Water Resources Research 50: 1-12. 
717 Kummu, M., and Varis, O. 2007. Sediment-related impacts due to upstream reservoir trapping, 718 the Lower Mekong River. Geomorphology 85: 275-293.

719 Kummu, M., Lu, X.X., Wang, J.J., and Varis, O. 2010. Basin-wide sediment trapping efficiency 720 of emerging reservoirs along the Mekong. Geomorphology 119: 181-197.

721 Lau, D.C.P., Leung, K.M.Y., and Dudgeon, D. 2009a. Are autochthonous foods more important than allochthonous resources to benthic consumers in tropical headwater streams? J. N. Am. Benthol. Soc. 28: 426-439.

724 Lau, D.C.P., Leung, K.M.Y., and Dudgeon, D. 2009b. What does stable isotope analysis reveal about trophic relationships and the relative importance of allochthonous and autochonous resources in tropical streams? A synthetic study from Hong Kong. Freshwater Biol. 54:

Lewis, W.M. Jr. 1988. Primary production in the Orinoco River. Ecology 69: 679-692.

Lewis, W.M. Jr., Hamilton, S.K., Rodriguez, M.A., Saunders III, J.F., and Lasi, M.A. 2001. Foodweb analysis of the Orinoco floodplain based on production estimates and stable isotope data. J. N. Am. Benthol. Soc. 20: 241-254.

Lowe-McConnell, R.H. 1975. Fish communities in tropical freshwaters. Longman, New Yori, NY.

734 Lu X.X., and Siew, R.Y. 2005. Water discharge and sediment flux changes in the Lower Mekong River. Hydrol. Earth Syst. Sc. 2: 2287-2325.

Lujan, N.K., German, D.P., and Winemiller, K.O. 2011. Do wood-grazing fishes partition their niche?: morphological and isotopic evidence for trophic segregation in Neotropical Loricariidae. Funct. Ecol. 25: 1327-1338. 
MacLeod, N.A., and Barton, D.R. 1998. Effects of light intensity, water velocity, and species composition on carbon and nitrogen stable isotope ratios in periphyton. Can. J. Fish. Aquat. Sci. 55: 1919-1925.

McCutchan, J.H. Jr., Lewis, W.M. Jr, Kendall, C., and McGrath, C.C. 2003. Variation in trophic shift for stable isotope ratios of carbon, nitrogen, and sulfur. Oikos 102: 378-390.

McIntyre, P.B., and Flecker, A.S. 2006. Rapid turnover of tissue nitrogen of primary consumers in tropical freshwaters. Oecologia 148: 12-21.

Mims, M.C., and Olden, J.D. 2013. Fish assemblages respond to altered flow regimes via

$$
\text { ecological filtering of life history strategies. Freshwater Biol. 58: 50-62. }
$$

Minson, D.J. 1971. Influence of lignin and silicon on a summative system of assessing the organic matter digestibility of Panicum. Aust. J. Agr. Res. 22: 589-598.

Mekong River Commission. 2003. State of the Basin Report 2003. Mekong River Commission,

752 Montoya, J.V., Roelke, D.L., Winemiller, K.O., Cotner, J.B., and Snider, J.A. 2006. Hydrological seasonality and benthic algal biomass in a Neotropical floodplain river. J.

Moore, J.W., and Semmens, B.X. 2008. Incorporating uncertainty and prior information into N. Am. Benthol. Soc. 25: 157-170.

Poff, N.L., Olden, J.D., Merritt, D.M., and Pepin, D.M. 2007. Homogenization of regional river stable isotope mixing models. Ecol. Lett. 11: 470-480.

Poff, N.L., Allan, J.D., Bain, M.B., Karr, J.R., Prestegaard, K.L., Richter, B.D., Sparks, R.E., and dynamics by dams and global biodiversity implications. Proc. Natl. Acad. Sci. 104: $5732-5737$. 
762 Poff, N. L., and Zimmerman, J.K.H. 2010. Ecological responses to altered flow regimes: a 763 literature review to inform the science and management of environmental flows.

$764 \quad$ Freshwater Biol. 55: 194-205.

765 Polis, G.A., Holt, R.D., Menge, B.A., and Winemiller, K.O. 1996. Temporal and spatial 766 components of food webs. In Food Webs: Integration of Patterns and Dynamics. Edited by 767 G.A. Polis and K.O. Winemiller. Chapman and Hall, N. Y. pp. 435-460.

768 Polis, G.A., Anderson, W.B., and Holt, R.D. 1997. Toward an integration of landscape and food 769 web ecology: the dynamics of spatially subsidized food webs. Annu. Rev. Ecol. Syst. 28: $770 \quad 289-316$.

771 Power, M.E., Parker, M.S., and Wootton, J.T. 1996. Disturbance and food chain length in rivers. 772 In Food Webs: Integration of Patterns and Dynamics. Edited by G.A. Polis and K.O. 773 Winemiller. Chapman and Hall, New York, NY. pp. 286-297.

774 Rai, H., and Hill, G. 1984. Primary production in the Amazonian aquatic ecosystem. In The 775 Amazon: limnology and landscape ecology of a mighty tropical river and its basin. 776 Edited by H. Sioli. Dr. W. Junk Publishers, Dordrecht, Germany. pp. 311-335.

777 Rainboth, W.J. 1996. Fishes of the Cambodian Mekong: FAO Species Identification Field Guide 778 for Fishery Purposes. Food and Agriculture Organization, Rome.

779 Rainboth, W.J., Vidthayanon, C. and Mai, D.Y. 2012. Fishes of the Greater Mekong Ecosystem 780 with Species List and Photographic Atlas. Ann Arbor, MI.

781 Rayner, T.S., Pusey, B.J., Pearson, R.G., and Godfrey, P.C. 2010. Food web dynamics in an 782 Australian wet tropics river. Mar. Freshwater Res. 61: 909-917. 
783 Renaud, S.M., Thinh, L.V., and Parry, D.L. 1999. The gross composition and fatty acid

784

785

786

787

788

789

790

791

792

793

794

795

796

797

798

799

800

801

802

803

804 composition of 18 species of tropical Australian microalgae for possible use in mariculture. Aquaculture 170: 147-159.

Richter, B.D., Postel, S., Revenga, C., Scudder, T., Lehner, B., Churchill, A., and Chow, M. 2010. Lost in development's shadow: the downstream human consequences of dams. Water Alternatives 3: 14-42.

Roach, K.A., Winemiller, K.O., Layman, C.A., and Zeug, S.C. 2009. Consistent trophic patterns among fishes in lagoon and channel habitats of a tropical floodplain river: Evidence from stable isotope. Acta Oecologica 35: 513-522.

Roach, K.A. 2013. Environmental factors affecting incorporation of terrestrial material into large river food webs. Freshwater Sc. 32: 283-298.

Roelke, D.L., Cotner, J.B., Montoya, J.V., Castillo, C.E.D., Davis, S.E., Snider, J.A., Gable, G.M., and Winemiller, K.O. 2006. Optically determined sources of allochthonous organic matter and metabolic characterizations in a tropical oligotrophic river and associated lagoon. J. N. Am. Benthol. Soc. 25: 185-197.

Sarkanen, K.V., and Ludwig, C.H. 1971. Lignins: occurrence, formation, structure, and reaction. Wiley, N.Y.

Thorp, J.H., and Delong, M.D. 1994. The riverine productivity model: an heuristic view of carbon sources and organic processing in large river ecosystems. Oikos 70: 305-308.

Thorp, J.H., Delong, M.D., Grrenwood, K.S., and Casper, A.F. 1998. Isotopic analysis of three food web theories in constricted and floodplain regions of a large river. Oecologia 117: $551-563$. 
805 Vander Zanden, M.J., Clayton, M.K., Moody, E.K., Solomon, C.T., and Weidel, B.C. 2015.

806 Stable isotope turnover and half-life in animal tissues: a literature synthesis. PLOS One

807 DOI:10.1371/journal.pone.0116182

808 Vannote, R.L., Minshall, G., Cummins, K.W., Sedell, J.R., and Cushing, C.E. 1980. The river continuum concept. Can. J. Fish. Aquat. Sci. 37: 130-137.

810 Welcomme, R.L. 1979. Fisheries Ecology of Floodplain Rivers. Longman, London.

811 Welcomme R.L. 1985. River Fisheries. Fisheries Technical Paper. Food and Agriculture 812 Organization, Rome, Italy.

813 Winemiller, K.O. 1990. Spatial and temporal variation in tropical fish trophic networks. Ecol. Monogr. 60: 331-367.

815 Winemiller, K.O. 1996. Factors driving spatial and temporal variation in aquatic floodplain food webs. In Food Webs: Integration of Patterns and Dynamics. Edited by G.A. Polis and K.O. Winemiller. Chapman and Hall, New York, NY. pp. 298-312.

Winemiller, K.O. 2004. Floodplain river food webs: generalizations and implications for fisheries management. In Proceedings of the Second International Symposium on the Management of Large Rivers for Fisheries Volume II. Regional Office for Asia and the

822 Winemiller, K.O., and Jepsen, D.B. 1998. Effects of seasonality and fish movement on tropical river food webs. J. of Fish Biol. 53: 267-296.

824 Winemiller, K.O., Montoya, J.V., Roelke, D.L., Layman, C.A., and Cotner, J.B. 2006. Seasonally varying impact of detritivorous fishes on the benthic ecology of a tropical floodplain river. J. N. Am. Benthol. Soc. 25: 250-262. 
827 Winemiller, K.O., Roelke, D.L., Cotner, J.B., Montoya, J.V., Sanchez, L., Castillo, M.M., 828 Montaña, C.G., and Layman, C.A. 2014. Top-down control of basal resources in a 829 cyclically pulsing ecosystem. Ecol. Monogr. 84: 621-635.

830 Winemiller, K.O., and 39 coauthors. 2016. Balancing hydropower and biodiversity in the Amazon, Congo, and Mekong. Science 351, in press.

832 Wissmar, R.C., Richey, J.E., Stallard, R.F., and Edmond, J.M. 1981. Plankton metabolism and carbon processes in the Amazon River, its tributaries, and floodplain waters, Peru-Brazil, May-June 1977. Ecology 62: 1622-1633.

835 Woodland, R.J., Rodriguez, M.A., Magnan, P., Glemet, H., and Cabana, G. 2012. Incorporating temporally dynamic baselines in isotopic mixing models. Ecology 93: 131-144.

837 Xia, B., Gao, Q.-F., Dong, S.-L., and Wang, F. 2013. Carbon stable isotope turnover and fractionation in grass carp Ctenopharyngodon idella tissues. Aquat. Biol. 19: 207-216.

Xue, Z., Liu, J.P., and Ge, Q. 2010. Changes in hydrology and sediment delivery of the Mekong River in the last 50 years: connection to damming, monsoon, and ENSO. Earth Surf. Processes Landforms 36: 296-308.

842 Zalinge, V.N., Nao, T.k, Touch, S. T., and Deap, L. 2000. Where there is water, there is fish? Cambodian fisheries issues in a Mekong River Basin perspective. In Common property in the Mekong: issues of sustainability and subsistence. Edited by M. Ahmed and P. Hlrsch. International Center for Living Aquatic Resources Management Studies and

847 Zeug, S.C., and Winemiller, K.O. 2008. Evidence supporting the importance of terrestrial carbon in a large-river food web. Ecology 89: 1733-1743.

849 Ziv, G., Baran, E., Nam, S., Rodriguez-Iturbe, I., and Levin, S.A. 2012. Trading-off fish 
850 biodiversity, food security, and hydropower in the Mekong River Basin. Proc. Natl.

$851 \quad$ Acad. Sci. 109: 5609-5614.

852 
853 Figure legends

854

855 Fig. 1. Map showing the Lower Mekong River, Cambodia, and locations of study sites (solid

856 black circles) on the Mekong, Sekong, Sesan and Srepok rivers.

857

858 Fig. 2. Biplots of $\delta^{13} \mathrm{C}$ and $\delta^{15} \mathrm{~N}$ values of primary producers and fishes from the four rivers

859 during the dry and wet seasons. Blue symbols represents the wet season, red symbols represent

860 the dry season, circles represent fish, squares represent benthic algae, triangles reprsent seston,

861 diamonds represent $\mathrm{C}_{3}$ macrophytes, and dashes (short horizontal lines) represent $\mathrm{C}_{4}$ grasses.

862

863 Fig. 3. Frequency histograms (percentage of fishes in the sample) for the 5th (left column) and

$86495^{\text {th }}$ (right column) percentile values for estimated percent contributions of alternative basal

865 production sources to fish biomass in the Mekong, Sekong, Sesan and Srepok rivers during the 866 dry season.

867

868 Fig. 4. Frequency histograms (percentage of fishes in the sample) for the 5th (left column) and $86995^{\text {th }}$ (right column) percentile values for estimated percent contributions of alternative basal 870 production sources to fish biomass in the Mekong, Sekong, Sesan and Srepok rivers during the 871 wet season.

872

873 Fig. 5. Frequency histograms for the 5th (left column) and $95^{\text {th }}$ (right column) percentile values

874 for estimated percent contributions of estimated percent contributions of alternative basal

875 production sources according to fish trophic guilds during the dry season. 